\title{
PENGEMBANGAN MEDIA PEMBELAJARAN INTERAKTIF BERBASIS ANDROID PADA MATERI POKOK ASAM BASA
}

\author{
Hasnawati $^{1}$, Ruslan ${ }^{2}$, Sugiarti $^{3}$ \\ ${ }^{1}$ Guru Kimia SMAN 6 Takalar \\ ${ }^{2,3}$ Dosen Program Pascasarjana Universitas Negeri Makassar \\ Email: hasna.chemistry@gmail.com
}

\begin{abstract}
ABSTRAK
Penelitian ini bertujuan mengembangkan media pembelajaran interaktif. Penelitian ini penelitian pengembangan menggunakan model pengembangan Plomp yang terdiri dari lima fase yaitu fase investigasi awal, fase desain, fase realisasi/konstruksi, fase tes, evaluasi dan revisi, dan fase implementasi. Subjek uji coba produk pengembangan ini adalah siswa kelas XI MIA1 SMA Negeri 6 Takalar dengan jumlah peserta didik 32 orang. Dalam penelitian ini, teknik pengumpulan data menggunakan kuesioner dengan skala Likert. Teknik analisis data yang digunakan yaitu analisis statistik deskriptif. Hasil penelitian menunjukkan bahwa untuk semua item dan aspek yang diukur, penilaian kevalidan media memperoleh kriteria valid, penilaian kepraktisan media adalah praktis. Hasil pretest-posttest gain $=0.798$ $(0,798>0,7=$ tinggi $)$. Dari hasil tersebut menujukkan media media pembelajaran interaktif berbasis android yang dikembangkan memiliki kategori valid, praktis dan efektif, sehingga dapat disimpulkan media pembelajaran interaktif berbasis android yang dikembangkan layak dijadikan sebagai media pembelajaran.
\end{abstract}

Kata kunci : Penelitian Pengembangan, Media Pembelajaran, Android, Plomp, Asam Basa.

\begin{abstract}
The study at developing interactive learning media. The study is research development by employing Plomp's development model which consist of five phase, namely initial investigation phase, design phase, realization/construction phase, test phase, evaluation and revision phase, and implementation phase. The subjects of tryout test were the students of grade XI MIA1 at SMAN 6 in Takalar with the total of 32 students. Data were collected by employing questionnaire with Likert scale. Data were analyzed by using descriptive statistics analysis. The results of the study reveal that all of the items and the aspects measured, the assessment of media validity obtained valid criteria, the assessment of media practicality was practical. The result of pretest-posstets gain $=0.798(0,798>0.7=$ high $)$. The aforementioned result indicates that interactive learning media based on android developed is valid category, practical, and effective. Thus, the conclusion is the interactive learning media based on android developed is feasible as learning media.
\end{abstract}

Keywords: Development Research, Learning Media, Android, Plomp, Acid-Base

\section{PENDAHULUAN}

Pendidikan merupakan salah satu faktor penting dalam pembangunan bangsa sehingga berbagai upaya dilakukan untuk meningkatkan kualitas pendidikan. Upaya peningkatan kualitas pendidikan tidak terlepas dari kualitas kegiatan pembelajaran di kelas hal ini merupakan salah satu bagian dari proses pendidikan yang bertujuan untuk 
membawa suatu keadaan baru yang lebih baik. Melalui pembelajaran yang tepat, peserta didik diharapkan mampu memahami, menguasai materi ajar sehingga hasil belajar peserta didik meningkat dan dapat berguna dalam kehidupan sehari-hari. Pembelajaran di Indonesia diarahkan untuk peserta didik mampu berfikir kreatif dan peserta didik lebih berperan aktif. Sumber belajar yang dapat digunakan peserta didik sangat banyak jenisnya, salah satunya adalah dengan memanfaatkan perkembangan Teknologi Informasi (TI). Dengan perkembangan Teknologi Informasi dunia pendidikan senantiasa bergerakmaju secara dinamis, khususnya dalam menciptakan atau membuat media, metode, dan materi pendidikan sehingga proses belajar dapat semakin menarik dan interaktif. Menurut Rusyan,dkk (1989) dalam membuat media pembelajaran sebaiknya pendidik juga memperhatikan perbedaan gaya belajar, kebutuhan dan karakteristik yang ada dalam pada peserta didik.

Media pembelajaran adalah suatu alat atau bahan yang mengandung informasi atau pesan pembelajaran. Oleh karena itu, sebaiknya pendidik dapat memanfaatkan media pembelajaran secara maksimal dalam proses belajar dan mengajar, dimana pendidik sebagai pemberi perhatian dan bimbingan kepada peserta didik, sedangkan media sebagai alat bantu penyampai informasi yang jelas dan menarik. Menurut Hofstetter dalam Munir (2002), multimedia interaktif adalah pemanfaatan komputer untuk menggabungkan teks, grafik, audio, gambar bergerak (animasi dan video) menjadi satu kesatuan dengan link dan tool yang tepat sehingga memungkinkan pemakainya melakukan navigasi, berinteraksi, berkreasi dan berkomunikasi.

Berdasarkan hasil observasi awal peserta didik yang dilakukan di SMAN 6 Takalar diketahui bahwa sebagian besar dari peserta didik telah memiliki komputer atau laptop dan secara keseluruhan memiliki smartphone. Peserta didik sering mengakses internet untuk memperoleh materi serta untuk mengerjakan tugas dan sebagai sarana interaksi sosial. Namun pada saat proses pembelajaran di dalam kelas, peserta didik masih menoton menggunakan buku paket. Selain itu pula peserta didik jarang menggunakan media pembelajaran. Serta jarang menggunakan Teknologi Informasi (TI) dalam proses pembelajaran. Setelah dilakukan pengecekan langsung pada daftar analisis nilai ulangan peserta didik, terkhusus pada mata pelajaran kimia masih ada sekitar $20 \%$ yang tidak tuntas untuk KKM 78.

Media pembelajaran berbasis android merupakan media pembelajaran alternatif yang memiliki karakteristik yang unik yaitu dapat digunakan di mana saja dan kapan saja, didukung dengan visualisasi yang menarik. Hal ini sesuai dengan pendapat Sadiman (2009) bahwa peserta didik dapat belajar secara tak langsung yaitu aktif berinteraksi dengan menggunakan media atau sumber belajar lain sehingga proses belajar dapat terjadi kapan saja dan di mana saja. Media tidak lagi hanya dipandang sebagai alat bantu belaka bagi pendidik untuk mengajar, tetapi lebih sebagai alat penyalur pesan dari pemberi pesan (pendidik) ke penerima pesan (peserta didik). Peserta didik dapat meningkatkan pemahaman kimia dan menyukai kimia sebagai pembelajaran yang menyenangkan lewat media pembelajaran. Media pembelajaran yang digunakan pendidik selama ini hanya bersifat informatif tanpa memperhatikan daya tarik peserta didik sehingga diperlukan media pembelajaran mandiri yang lebih menarik bagi peserta didik. Hasil penelitian Prasetyo (2015), menunjukkan bahwa media pembelajaran kimia berbasis android dapat memberikan pengaruh yang signifikan terhadap peningkatan motivasi belajar peserta didik.

Smartphone memiliki banyak kegunaan yang bisa dimanfaatkan sebagai media dalam pembelajaran. Menurut Kuhn and Vogt, (2013) melaporkan bahwa smartphone merupakan piranti yang sangat cocok digunakan sebagai alat bantu eksperimen karena alat ini dilengkapi dengan berbagai macam sensor. 
Pemanfaatan smartphone dalam pembelajaran khususnya kimia akan mampu mendorong keikutsertaan siswa dalam pembelajaran. Menurut Song et al., (2012) menemukan bahwa pembelajaran yang memanfaatkan perangkat mobile mampu memfasilitasi siswa untuk mendapatkan pembelajaran yang bersifat personal dan sesuai dengan kebutuhan individu siswa.

Materi asam basa adalah salah satu pokok bahasan yang ada dalam materi ajar kimia SMA kelas IX yang seharusnya menyenangkan ketika dipelajari dikelas karena berhubungan dengan kehidupan sehari-hari. Selain itu materi asam basa juga merupakan hal yang paling penting untuk peserta didik memahami konsep didalamnya karena merupakan bekal untuk lanjut ke materi selanjutnya. Namun peserta didik justru menganggap sebagai materi yang sangat susah. Hal ini karena kimia sering dihubungkan dengan hal-hal yang sulit dibawa ke alam nyata. Oleh karena itu dibutuhkan suatu media pembelajaran yang mampu membantu peserta didik dalam memahaminya.

Penelitian yang dilakukan oleh Lubis, dkk (2015) menunjukkan bahwa media pembelajaran dapat digunakan sebagai suplemen belajar yang dapat meningkatkan motivasi belajar dan prestasi kognitif siswa SMA. Selain itu adapun penelitian yang dilakukan oleh Yektyastuti, dkk (2015) mengatakan bahwa terdapat perbedaan yang signifikan pada peningkatan kemandirian belajar antara kelas eksperimen yang menggunakan media pembelajaran dan kelas kontrol yang tidak menggunakan media pembelajaran.

Berdasarkan uraian di atas maka peneliti termotivasi untuk melakukan penelitian dengan judul, "Pengembangan Media Pembelajaran Interaktif Berbasis Android pada Materi Pokok Asam Basa". Peneliti berharap dengan adanya media tersebut, maka peserta didik dapat termotivasi dan dapat meningkatkan hasil belajar peserta didik, serta dapat membuat peserta didik tambah tertarik untuk mempelajari kimia khususnya materi Asam Basa.

\section{METODE PENELITIAN}

Penelitian ini adalah penelitian pengembangan (Research and Development) yang bertujuan untuk mengembangkan media pembelajaran interaktif pada materi pokok Asam-Basa dengan menggunakan program android studio yang mengacu pada model pengembangan Plomp. Penelitian ini dilaksanakan di SMA Negeri 6 Takalar dan subyek ujicoba penelitian adalah peserta didik kelas XI MIA 1 dengan jumlah peserta didik 32 orang.

Pengembangan media pembelajaran menggunakan pengembangan Plomp terdiri dari lima fase yaitu fase investigasi awal (prelimenary investigation), fase desain (design), fase realisasi/konstruksi (realization/construction), fase tes, evaluasi dan revisi (test, evaluation and revision) dan implementasi (implementation).

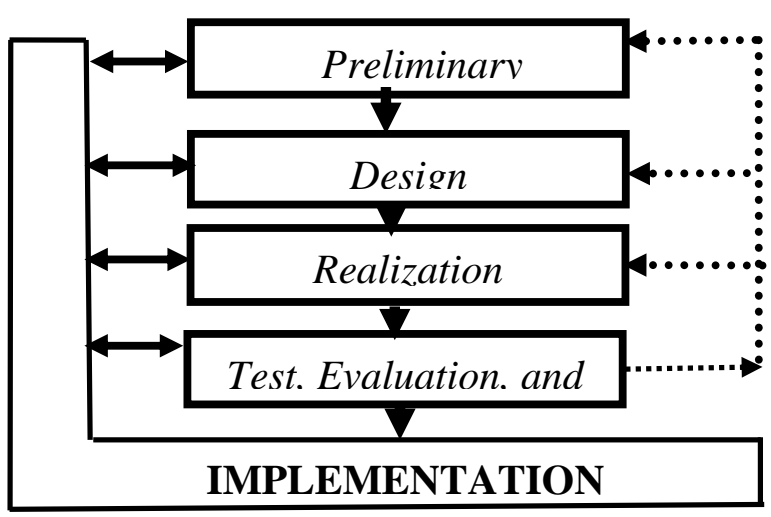

Gambar 1. Diagram Model Pengembangan Plomp

Instrumen penelitian yang digunakan untuk mengumpulkan data adalah kuesioner/angket. Instrumen kuesioner pada penelitian pengembangan ini berupa lembar validasi oleh ahli materi, lembar validasi oleh ahli media, lembar respon guru dan peserta didik, lembar pengamatan pengelolaan pembelajaran, lembar aktifitas peserta didik. Sedangkan data tes hasil belajar diperoleh dari pemberian pretestposttest. 
Teknik pengumpulan data menggunakan kuesioner dengan skala Likert. Teknik analisis data yang digunakan yaitu analisis statistic deskriptif.

\section{HASIL DAN PEMBAHASAN}

1. Proses Pengembangan Pembelajaran Interaktif

Media Android

\section{a. Deskripsi Investigasi Awal}

Tahap perencanaan awal dimulai dengan adanya ide atau gagasan untuk menghasilkan suatu produk yang didapatkan berdasarkan studi pendahuluan yang telah dilakukan yaitu tahapan pengumpulan informasi dan identifikasi permasalahan, lalu analisis konsep. Studi pendahuluan ini meliputi observasi, wawancara dengan pendidik dan pemberian angket kepada peserta didik.

Hasil observasi dan wawancara terhadap pendidik diperoleh gambaran bahwa sebagian besar pendidik masih menggunakan model dan metode yang monoton yaitu pembelajaran langsung dan ceramah. Serta pendidik merasa belum puas karena masih banyak peserta didiknya yang kurang memperhatikan materi sehingga ada peserta didik yang hasil belajarnya rendah. Pendidik menginginkan sebuah inovasi yang dapat dikembangkan lagi dalam proses pembelajaran. Oleh karena itu, pendidik sangat mengharapkan pembelajaran yang variatif dengan menggunakan media yang inovatif.

Pemberian angket dilakukan kepada peserta didik. Hasil angket yang diperoleh bahwa peserta didik menyukai belajar kimia, tetapi peserta didik kurang tertarik dalam belajar kimia karena dianggap sulit dan membosankan. Peserta didik sangat menyukai bila pendidik menggunakan beragam media pembelajaran. Peserta didik berharap pelajaran kimia bisa dibuat menarik dengan menggunakan media pembelajaran interaktif. Oleh karena itu pendidik dan peserta didik sangat berharap dan bersemangat jika ada sesuatu yang baru yang dapat digunakan dalam proses pembelajaran. Serta adanya media yang dapat dijadikan sebagai alternatif dalam proses pembelajaran sehingga peserta didik dapat belajar mandiri dengan motivasi belajar yang tinggi. Hal ini memberi dorongan bagi peneliti untuk mengembangkan media pembelajaran interaktif sehingga dapat digunakan oleh peserta didik untuk belajar asam basa dan memudahkan pendidik dalam mengajarkan materi tersebut.

Tabel 4.1. Hasil Analisis Kebutuhan dari Hasil Wawancara dan Observasi

\begin{tabular}{|c|c|c|}
\hline No & $\begin{array}{c}\text { Aspek } \\
\text { kebutuhan }\end{array}$ & Deskripsi \\
\hline 1 & $\begin{array}{c}\text { Wawancara } \\
\text { guru }\end{array}$ & 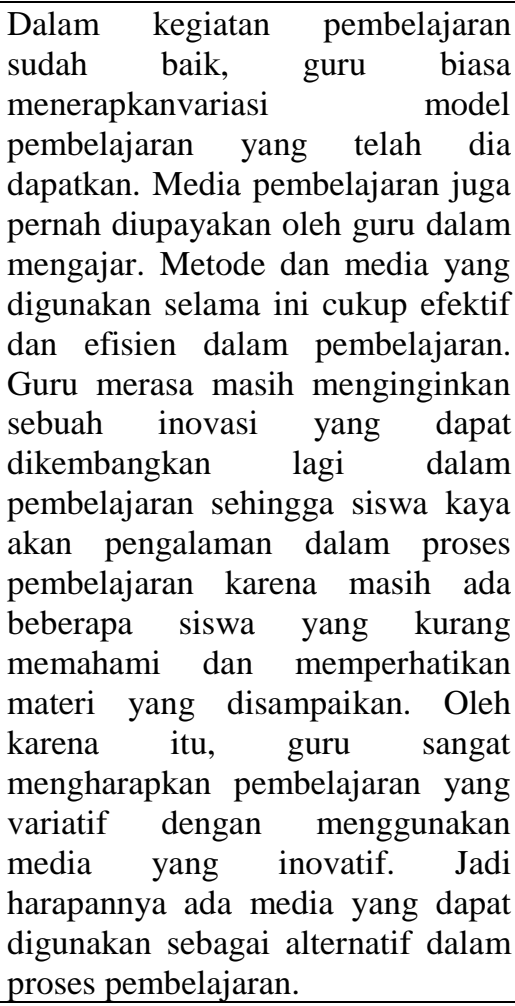 \\
\hline 2 & $\begin{array}{l}\text { Angket } \\
\text { Peserta } \\
\text { Didik }\end{array}$ & $\begin{array}{l}\text { Peserta didik sudah tertarik belajar } \\
\text { kimia, hanya saja karena menurut } \\
\text { mereka belajar kimia itu sulit } \\
\text { sehingga memengaruhi mina } \\
\text { tmereka. Siswa menyukai bila guru } \\
\text { menggunakan beragam media } \\
\text { pembelajaran dalam proses } \\
\text { pembelajaran. }\end{array}$ \\
\hline 3 & Fasilitas & $\begin{array}{l}\text { Cukup memadai sebagai syarat } \\
\text { terciptanya pembelajaran. Ruangan } \\
\text { kelas, bangku dan meja yang cukup } \\
\text { untuk siswa, papan tulis, dan ada } \\
\text { LCD proyektor yang dapat diambil } \\
\text { di ruangan guru }\end{array}$ \\
\hline 4 & $\begin{array}{l}\text { Analisis } \\
\text { konsep }\end{array}$ & Menggunakan kurikum 2013 \\
\hline
\end{tabular}


b. Deskripsi Fase Desain

Pada tahap ini, dihasilkan rancangan media pembelajaran dan instrumen yang digunakan untuk menilai media yang terdiri dari lembar validasi media, angket respon pendidik dan angket respon peserta didik. Media pembelajaran dirancang berdasarkan hasil dari analisis konsep dan analisis kurikulum yang digunakan oleh sekolah tersebut. Software utama yang digunakan pada media ini adalah Android Studio. Materi yang ditampilkan pada setiap slide dirancang sedemikian rupa agar setiap konsep pada materi asam basa mampu dimengerti dengan baik oleh peserta didik. Dengan demikian diharapkan peserta didik akan lebih bersemangat dalam mempelajari asam basa.

c. Deskripsi Fase Realisasi/Konstruksi

Fase ini merupakan lanjutan dari fase sebelumnya yaitu perancangan. Pada fase ini dihasilkan media pembelajaran interaktif I (awal) sebagai realisasi hasil perancangan media pembelajaran. Hasil-hasil konstruksi diteliti kembali apakah kecukupan teoriteori pendukung media telah terpenuhi dan diterapkan dengan baik pada setiap komponen media sehingga siap diuji kevalidannya oleh validator.

d. Deskripsi Fase Tes, Evaluasi dan Revisi

Pada fase ini, kegiatan yang dilakukan yaitu kegiatan validasi. Setelah media pembelajaran interaktif kimia asam basa berbasis android selesai (draft awal), maka dilakukan uji validitas terhadap validator (expert review) yang terdiri dari dua validator. Uji validitas bertujuan untuk melihat kekurangan dari draft I baik dari segi isi materi (content) maupun dari tampilan (layout).

Kegiatan validasi media pembelajaran diawali dengan memberikan media pembelajaran dalam bentuk file beserta lembar penilaian kepada 2 orang validator. Penilaian kelayakan media ditinjau dari kevalidannya dilakukan oleh dua dosen jurusan Kimia FMIPA UNM yang memiliki kompetensi sebagai ahli media dan satu dosen yang memiliki kompetensi sebagai ahli materi.

1) Validasi Tahap Pertama Media

Tabel 4.3 Saran Berdasarkan Hasil Uji Validitas untuk Draft I

\begin{tabular}{|c|l|c|l|}
\hline N0 & \multicolumn{1}{|c|}{ NAMA } & PEKERJAAN & \multicolumn{1}{|c|}{ SARAN } \\
\hline 1 & Drs. Hj. Sumiati Side, & Ketua Jurusan \\
Kimia UNM & $\begin{array}{l}\text { Sebagai ahli materi } \\
\text { M.Si }\end{array}$ & $\begin{array}{l}\text { Desain tampilan diperbaiki, } \\
\text { terlalu banyak kalimat } \\
\text { - Ukuran Huruf diperbesar }\end{array}$ \\
\hline 2 & Dr. Muhammad & Dosen Jurusan & $\begin{array}{l}\text { - Salah satu ikon pada slide } \\
\text { awal tidak bias dijalankan }\end{array}$ \\
& Anwar, M. Si & Kimia UNM & $\begin{array}{l}\text { Kecepatan pergantian antar } \\
\text { slide terlalu lambat }\end{array}$ \\
\hline
\end{tabular}

Tabel 4.4 Hasil Penilaian Terhadap Media oleh Para Ahli (Validasi I)

\begin{tabular}{|c|c|c|c|}
\hline No & Bidang Telaah & $\bar{V}$ & Keterangan \\
\hline 1 & Materi & 3,2 & $\mathrm{~V}$ \\
\hline 2 & Bahasa & 3,12 & V \\
\hline 3 & Penyajian & 3 & V \\
\hline 4 & Kualitas Tampilan & 2,86 & V \\
\hline 5 & Daya Tarik & 3 & V \\
\hline & Rata-rata & 3,03 & $\mathrm{~V}$ \\
\hline
\end{tabular}

$$
\begin{array}{cl}
\text { Keterangan: SV (Sangat Valid) } & \text { jika } 3,5 \leq V \leq 4 \\
\text { V (Valid) } & \text { jika } 2,5 \leq V<3,5 \\
\text { CV (Cukup Valid) } & \text { jika } 1,5 \leq V<2,5 \\
\text { TV (Tidak Valid) } & \text { jika } V<1,5
\end{array}
$$

2) Validasi Tahap Kedua Media

Tahap ini dilakukan sebelum melanjutkan penelitian ke tahap selanjutnya yaitu tahap uji coba produk. Penilaian dilakukan oleh ahli media dan ahli materi dengan tujuan untuk mengetahui kelayakan desain media dan produk media. Penilaian dilakukan dengan menggunakan angket media pembelajaran. Penilaian ahli media maupun ahli materi menunjukkan desain media yang dihasilkan sudah layak untuk dikembangkan.

Validator ahli materi dan ahli media menyukai media pembelajaran interaktif berbasis android yang telah dibuat dan menyarankan untuk segera melanjutkan penelitian ke tahap selanjutnya. Hasil dari penilaian validasi tahap kedua adalah media pembelajaran yang dikembangkan layak untuk diujicobakan. 
Tabel 4.5 Hasil Penilaian Terhadap Media oleh Para Ahli (Validasi II)

\begin{tabular}{|c|c|c|c|}
\hline No & Bidang Telaah & $\bar{V}$ & Keterangan \\
\hline 1 & Materi & 3,20 & V \\
\hline 2 & Bahasa & 3,12 & V \\
\hline 3 & Penyajian & 3,08 & V \\
\hline 4 & Kualitas Tampilan & 3,2 & V \\
\hline 5 & Daya Tarik & 3,06 & V \\
\hline \multicolumn{2}{|c|}{} \\
\hline
\end{tabular}

Keterangan: $\quad$ SV (Sangat Valid) jika $3,5 \leq V \leq 4$

$\mathrm{V}$ (Valid) jika $2,5 \leq V<3,5$

CV (Cukup Valid) jika $1,5 \leq V<2,5$

TV (Tidak Valid) jika $V<1,5$

Dapat disimpulkan bahwa media pembelajaran interaktif kimia asam basa berbasis android sudah termasuk dalam kategori "Valid" dengan rentang $2,5 \leq \bar{V} \leq 3,5$. Berdasarkan kriteria kevalidan, maka perangkat pembelajaran tersebut telah memiliki derajat validitas yang memadai dan layak untuk digunakan sebagai media pembelajaran.

e. Deskripsi Fase Implementasi

1) Uji Coba Kelompok Kecil

Uji coba kelompok kecil dilakukan sebelum uji coba produk di lapangan. Uji coba dilakukan kepada 10 orang peserta didik untuk melihat respon peserta didik terhadap media pembelajaran interaktif berbasis android yang dikembangkan sebagai media pembelajaran kimia. Hal ini juga dilakukan untuk melihat segala kemungkinan masalah yang dapat diperoleh di lapangan pada saat uji coba terbatas, sehingga masalah yang ditemukan dapat segera dicarikan solusinya guna pengembangan media lebih baik lagi.

Hasil uji coba kelompok kecil, ternyata dalam waktu yang bahkan melebihi dari waktu yang telah ditentukan, ada 5 peserta didik yang masih kesulitan dan belum berhasil menyelesaikan media ini karena hp android peserta didik yang lambat dalam menjalankan aplikasi dan yang paling penting ketelitian peserta didik sangat perlu. Sehingga ini menjadi bahan evaluasi tersendiri bagi peneliti.

2) Uji Coba Terbatas

a) Hasil respon peserta didik dan pendidik
Pada fase ini, kegiatan yang dilakukan yaitu kegiatan ujicoba terbatas. Setelah media pembelajaran interaktif kimia asam basa berbasis android yang telah divalidasi dan memenuhi standar kevalidan, maka dilakukan uji coba pada kelas XI MIA, SMA Negeri 6 Takalar dengan peserta didik sebanyak 32 orang yang terdiri dari 12 orang laki-laki dang 20 orang perempuan. Hal ini dilakukan untuk mengujicobakan media tersebut.

Pembelajaran dilakukan di dalam kelas dengan mengkondisikan dua hp android untuk empat orang peserta didik. Pada kegiatan pembelajaran, peserta didik mempelajari secara mandiri materi asam basa dengan cara mengeksplorasi media pembelajaran interaktif kimia asam basa berbasis android dengan waktu kegiatan selama 6x pertemuan. Selanjutnya peserta didik mengisi angket.

Tabel 4.6 Hasil Angket Respon Peserta Didik terhadap Media Pembelajaran

\begin{tabular}{|c|c|c|c|c|}
\hline No & Nilai & Kategori & Frekuensi & Persentase $(\%)$ \\
\hline 1 & $85-100$ & Sangat Baik & 8 & 25,00 \\
\hline 2 & $65-84$ & Baik & 22 & 68,75 \\
\hline 3 & $55-64$ & Kurang Baik & 2 & 6,25 \\
\hline 4 & $35-54$ & Tidak Baik & 0 & 0 \\
\hline 5 & $0-34$ & Sangat Tidak Baik & 0 & 0 \\
\hline
\end{tabular}

Angket respon peserta didik menunjukkan bahwa sebesar $68,75 \%$ peserta didik berada pada kategori baik dan $25,00 \%$ peserta didik berada pada kategori sangat baik yang berarti peserta didik memberikan respon positif terhadap media pembelajaran.

\begin{tabular}{|c|c|c|c|c|c|c|c|c|c|c|c|c|c|}
\hline \multirow{2}{*}{ RESPONDEN } & \multicolumn{10}{|c|}{ ITEM } & \multirow{2}{*}{ JUMLAH } & \multirow{2}{*}{$\begin{array}{c}\text { Persentase } \\
\text { (\%) }\end{array}$} & \multirow{2}{*}{ Ketegor } \\
\hline & 1 & 2 & 3 & 4 & 5 & 6 & 7 & 8 & 9 & 10 & & & \\
\hline Guru 1 & 4 & 4 & 4 & 5 & 4 & 5 & 5 & 4 & 4 & 4 & 43 & 86 & SB \\
\hline Guru 2 & 5 & 4 & 4 & 4 & 5 & 5 & 4 & 4 & 5 & 4 & 42 & 84 & SB \\
\hline Guru 3 & 5 & 5 & 4 & 4 & 4 & 4 & 4 & 4 & 5 & 4 & 43 & 86 & SB \\
\hline
\end{tabular}

$\begin{array}{ll}\text { Keterangan: } & \\ \text { Kategori } & \\ \text { SangatBaik(SB) } & =80 \%-100 \% \\ \text { Baik (B) } & =65 \%-84 \% \\ \text { KurangBaik(KB) } & =55 \%-64 \% \\ \text { Tidak Baik(TB) } & =35 \%-54 \% \\ \text { Sangat Tidak Baik(STB) } & =0 \%-34 \%\end{array}$

Selanjutnya yaitu hasil analisis deskriptif secara kuantitatif respon pendidik terhadap media pembelajaran asam basa menunjukkan bahwa pendidik memberikan 
respon positif karena berada pada kategori sangat baik.

b) b) Hasil pretest-posttest peserta didik

Hasil belajar peserta didik diperoleh dengan tes evaluasi pilihan ganda yang diberikan sebelum dan setelah menggunakan media pembelajaran interaktif kimia berbasis android. Kategori peningkatan yang digunakan adalah tinggi apabila $g>0,7$; sedang apabila $0,7>g>0,3$; dan rendah apabila $g<0,3$. Berdasarkan hasil yang diperoleh, terdapat peningkatan hasil belajar peserta didik karena gain berada pada $0,798>0,7$, sehingga dapat disimpulkan peningkatan hasil belajar berada pada kategori tinggi.

Adapun kriteria keefektifan selanjutnya yaitu terlaksananya aktivitas peserta didik minimal terhadap $70 \%$ aspek yang diamati. Hal ini berarti dari 8 aktivitas peserta didik yang diamati, 6 diantaranya harus terlaksana. Berdasarkan hasil analisis data aktivitas peserta didik menunjukkan bahwa delapan kategori pada aktivitas peserta didik terpenuhi yaitu:

1. Memperhatikan informasi dan mencatat seperlunya

2. Mengakses/membaca materi pelajaran

3. Aktif terlibat dalam tugas

4. Aktif berdiskusi dengan teman

5. Mencatat apa yang disampaikan teman/guru

6. Mengajukan pertanyaan kepada teman/guru

7. Menjawab/ menanggapi pertanyaan teman/guru

Selama kegiatan pembelajaran dengan media pembelajaran interaktif kimia asam basa berbasis android peserta didik terlibat aktif sehingga dominasi pendidik dalam pembelajaran dapat dikurangi. Dengan demikian dapat disimpulkan bahwa media pembelajaran interaktif kimia asam basa berbasis android mengoptimalkan peserta didik dalam pembelajaran sehingga lebih mandiri.

Dari uraian di atas dapat disimpulkan bahwa media pembelajaran interaktif berbasis android memenuhi kriteria keefektifan yaitu aktivitas peserta didik memenuhi batas toleransi yang telah ditentukan.

\section{SIMPULAN DAN SARAN}

1. Pengembangan media pembelajaran ini menggunakan model pengembangan Plomp yang meliputi lima fase yaitu fase investigasi awal yang mencakup observasi awal di sekolah, melakukan wawancara, melakukan pengumpulan data analisis respon siswa terhadap media pembelajaran dengan menggunakan angket; fase desain media; tahap reaslisasi/kontruksi; fase tes, evaluasi dan revisi dengan cara validasi media oleh validator dan fase implementasi dengan melakukan uji coba terbatas.

2. Media pembelajaran asam basa yang dikembangkan termasuk dalam kategori "valid" dengan nilai yang diperoleh dari kedua validator rata-rata 3 dan "praktis" dengan persentase untuk pendidik "sangat setuju" sebesar $85 \%$ dan untuk peserta didik "sangat setuju" sebesar 25,00\% dan "setuju" sebesar $68,75 \%$. Serta keefektifan dilihat dari hasil belajar peserta didik berupa pretest-posttest menunjukkan gain $(\mathrm{g})=0,798$. Berdasarkan hasil yang diperoleh, gain berada pada 0,798>0,7 yang berarti terdapat peningkatan hasil belajar peserta didik pada kategori tinggi. Dari hasil kevalidan, kepraktisan dan keefektifan tersebut, dapat disimpulkan bahwa media pembelajaran interaktif kimia asam basa berbasis android yang dikembangkan layak dijadikan sebagai media pembelajaran.

\section{DAFTAR RUJUKAN}

Archambault, J. 2008. "The Effect of Developing Kinematics Concepts Graphically Prior to Introducing Algebraic Problem Solving Techniques".Action Research Reguared for the Master of Natural 
Science Degree with Concentration in Physics. Arizona State University.

Ardiansyah, Firdan. 2011. Pengenalan

Dasar Android Programming. Depok :

Biraynara.

Arikunto, Suharsimi. 2010. Dasar-Dasar Evaluasi Pendidikan. Jakarta: Bumi Aksara.

Arsyad, A. 2011. Media pembelajaran. Jakarta: PT Raja Grafindo Persada.

Budhi Haryanto, Ika, dkk. 2012. Pengembangan Media CD Interaktif Pembelajaran Geografi Materi Tenaga Endogen Siswa Kelas X. Edu Geography. Vol 1 (1). Semarang : Jurusan Geografi Fakultas Ilmu Sosial Universitas Negeri Semarang.

Borg, W. R., \& Gall, M. D. 1989. Educational Research: an Introduction. New York: Longman.

Darwis, Muhammad. 2007. Model Pembelajaran Matematika yang Melibatkan Kecerdasan Emosional. Disertasi. Tidak diterbitkan. Program Pascasarjana Program Studi Pendidikan Matematika Universitas Negeri Surabaya.

Depdiknas, 2003. Kurikulum Berbasis Kompetensi. Jakarta: Pusat Kurikulum, Balitbang Depdiknas

Hobri, 2009. Metodologi Penelitian Pengembangan (Developmental Research) (Aplikasi pada Penelitian Pendidikan Matematika). Jakarta : Word Editor

Kuhn, J., Vogt, P., 2013. Smartphones as experimental tools: Different methods to determine the gravitational acceleration in classroom physics by using everyday devices. Eur. J. Phys. Educ. 4.

Lubis, I.R., Sugiyarto, K.H., Ikhsan, J., 2015. Pengembangan Media Mobile Learning "CHEMONDRO" Berbasis Android sebagai Suplemen Belajar Siswa SMA, in: Prosiding SNPS (Seminar Nasional Pendidikan Sains). pp. 468-477.

Mardikaningtyas, Dyah Afiat, Ibrohim dan Endang Suarsini. (2016).
Pengembangan Pembelajaran

Pencemaran Lingkungan Berbasis

Penelitian Fitoremediasi untuk Menunjang Keterampilan Ilmiah, Sikap Peduli Lingkungan dan Motivasi Mahasiswa pada Matakuliah Dasar-Dasar Ilmu Lingkungan. Jurnal Pendidikan: Teori, Penelitian dan Pengembangan. Volume 1, Nomor 3 : 499-506

Munir. 2002. Multimedia. Bandung : Alfabeta.

Muslim, Riski. 2015. Membuat Aplikasi Andorid dengan Android Studio. Depok : Biraynara.

Nieveen, Nienke. 1999. Prototyping to Reach Product Quality. In Jan Van den Akker, R.M. Branch, K. Gustafson, N. Nieveen \& $\mathrm{Tj}$. Plomp (Eds). Design Approaches and Tools in Education and Training (pp 125 - 135) Kluwer Academic Publishers, Dordrecht, the Nederlands.

Nurdin. 2007. Model pembelajaran Matematika Yang Menumbuhkan

Kemampuan Metakognitif Untuk Menguasai bahan Ajar. Disertasi. Tidak diterbitkan. Surabaya: UNESA.

Prasetyo. 2015. Pengaruh Penggunaan Media Pembelajaran Kimia Berbasis Android terhadap Peningkatan Motivasi Belajar Siswa SMA. Prosiding Seminar Nasional Pendidikan Sains. 24074659.

Rusyan, A.T., Kusdinar, A., Arifin, Z., 1989. Pendekatan dalam proses belajar mengajar. Remadja Karya CV.

Sadiman, Arief S, dkk. 2009. Media Pendidikan (Pengertian, Pengembangan, dan Pemanfaatannya). Jakarta : PT Raja Grafindo Persada.

Song, Y., Wong, L.-H., Looi, C.-K., 2012. Fostering personalized learning in science inquiry supported by mobile technologies. Educ. Technol. Res. Dev. 60, 679-701. 
Sugiyono, M. P. P. (2007). Pendekatan Kuantitatif. Kualitatif, Dan $R \& D$, Bandung: Alfabeta.

Tanrere, M., Side, S., 2012. Pengembangan Media Chemo-Edutainmentmelalui Software Macromedia Flash MX pada Pembelajaran IPA Kimia SMP. J. Pendidik. Dan Kebud. 18, 156162.Menggunakan Laboratorium Konvensional dan Virtual Laboratorium Terhadap Hasil Belajar Siswa. Makassar: FMIPA UNM.

Trianto. 2007. Model Pembelajaran Terpadu dalam Teori dan Praktek. Jakarta : Prestasi Pustaka Publishing. Wahono,Romi Satria. 2006. Aspek dan Kriteria Penilaian Media Pembelajaran. Jakarta : PT Raja Grafindo Persada.

Yani, A. (2011). Pengembangan Perangkat Pembelajaran Mata Kuliah Fisika Dasar yang Kontekstual Berbasis Komputer pada Program Studi Pendidikan Fisika, FMIPA Universitas Negeri Makassar. Makassar: Jurusan Fisika UNM.

Yektyastuti, R., Prasetyo, Y.D., Mardiana, T., Ikhsan, J., Sugiyarto, K.H., 2015. Penggunaan Media Pembelajaran Kimia "CHEMONDRO" pada Materi Kelarutan dan Pengaruhnya terhadap Kemandirian Belajar Siswa SMA, in: Prosiding SNPS (Seminar Nasional Pendidikan Sains). pp. 8087. 